\title{
Behavior of Precast Reinforced Concrete Beam-Column Connection by Double Straight Notch Models under Lateral Cyclic Loading
}

\author{
Ruminsar Simbolon', Herman Parung², Rita Irmawaty ${ }^{3}$ and Arwin Amiruddin ${ }^{4}$ \\ Civil Engineering Department, Hasanuddin University, Makassar, Indonesia
}

\begin{abstract}
The connection in precast concrete structures is an attenuation especially against the lateral forces due to the earthquake. This research is an experimental study in a laboratory with full scale, investigates the performance of two types of momentresisting connections, and compare to monolithic type, on the connection of precast beam-column, subjected to cyclic lateral load. The connection performance was evaluated including strength, deformation ductility, stiffness, crack pattern, failure mode, and energy absorption rate. The experimental results show that the failure of all specimens is considered a bending failure, which indicates that most of the cracks are oblique perpendicular to the direction of loading. It was found that the monolithic type performed more satisfactorily on strength than the two types of connection, due to its higher bending strength capacity. However, the STR-2 type is better able to absorb energy and has the lowest reduction in stiffness. Based on the acceptance criteria of ACI 374.1-05 and SNI 7834;2012, the test results show that both types of precast connections generally meet the requirements as moment-resistant precast concrete beam-column connections and can be used in precast concrete buildings with the highest earthquake risk level in Indonesia.
\end{abstract}

Keywords: Cyclic lateral load, crack features, Ductility, Energy dissipation, Monolithic, Stiffness.

\section{INTRODUCTION}

Precast concrete cannot be widely used in the scope of construction, because the reliability of connections is still an obstacle, especially against earthquake loads. Indonesia due to its location and geographical conditions are often hit by large earthquakes, makes the use of precast concrete construction very risky. Apart from having sufficient strength to withstand the working forces, the connection must also have sufficient ductility to undergo major deformation before failure. In addition, as an moment-resisting ductile precast concrete beam-column connection must be required to meet other criteria such as absorbing energy, strong column weak beam, strength degradation and stiffness degradation.
Two types of connections investigated in this study namely double notch type 1 (STR-1), and double notch type 2 (STR-2) which were subjected to lateral cyclic loads. The beam and column dimensions, the strength of precast concrete, and configuration details were kept constant to afford a direct comparison. The only difference was the steel ratio of the splicing tension and compression bar in the connecting beams. Modeling boundary conditions follow the portal deformation pattern due to lateral loads. The connections are evaluated based on their performance in terms of strength, deformation ductility, stiffness, strong column weak beam, crack features, energy dissipation, and compared to monolithic.

\section{MATERIALS AND METHODS}

\section{A. Specimen Details and Design Criteria}

Two beam-column joint specimens and one monolith were fabricated, subjected to cyclic lateral loads, and tested at full scale. Specimens represented an exterior joint of a fifth story building. The Yield strength of threaded reinforcement is 400 $\mathrm{MPa}$. The joint between precast and cast concrete in situ, are injected with a non-shrink type grouting mortar to increase the direct shear strength of the joint. For connection STR-1, the notch in the form of an asymmetrical hook in the precast beam has been formed at the factory and the notch in the beamcolumn beam section is monolith and mortar grouting injection at three points.

For STR-2, notches in precast beams are formed when joining beam to column, while the notches in the beam section of the beam-column are monoliths and mortar grouting injection was carried out at two points. Continuity precast beam with beamcolumn was achieved with splicing reinforcement of the precast beam, to the beam of beam-column. Figure 1 shows the geometry of the STR-1 and STR-2 specimens. the length of the beam is $1925 \mathrm{~mm}$ on the column with a medium height of $1130 \mathrm{~mm}$. The Column is square with sides $300 \mathrm{~mm}$. the beam section on STR-1 and STR-2 is square with dimensions 250x300 mm. The size displayed corresponds to the distance between the hinged supports. 


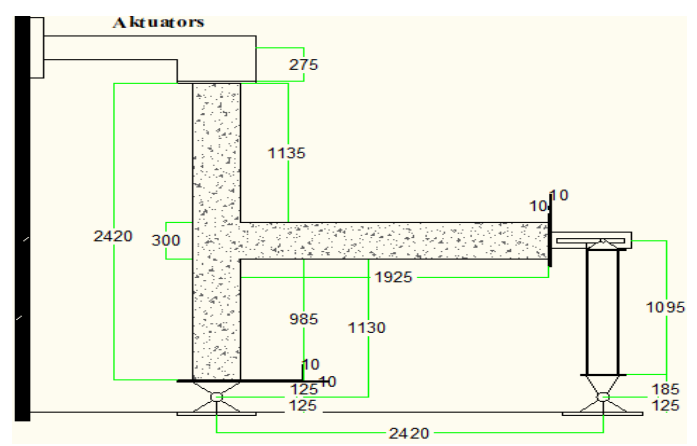

Side view

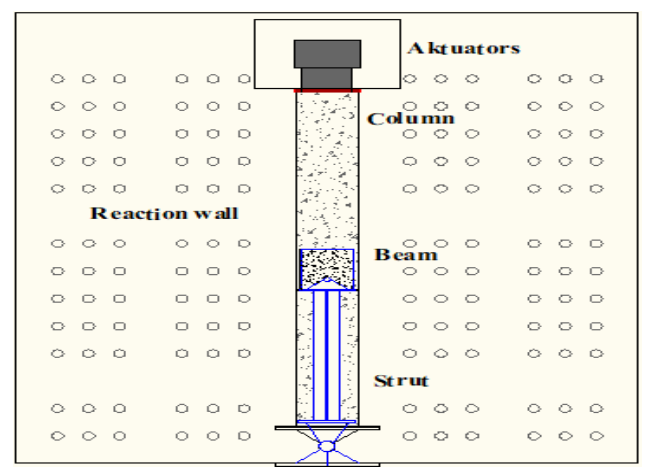

Front view

Fig. 1. Specimen Geometry

Specimens were designed according to the Indonesian Building Code, SNI 2847:2013 [5], and SNI 1726:2019 [4].. The detailing of the reinforcement in the beam-column relationship will make plastic hinges occur in the beam. Meanwhile, the notch system and the use of non-shrinkage mortar as grouting in the joint are expected to increase the flexural strength and shear capacity of the joint.

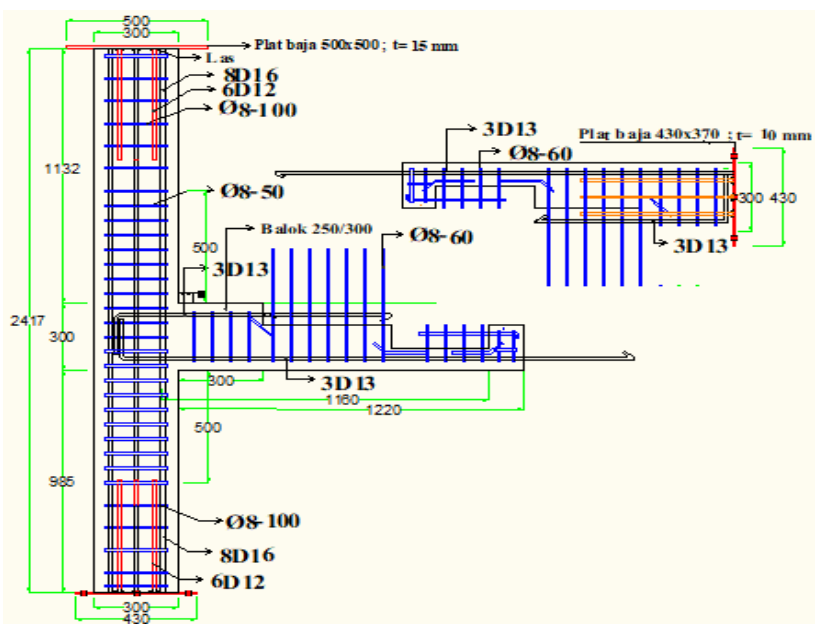

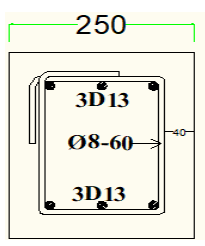

Section 1-1

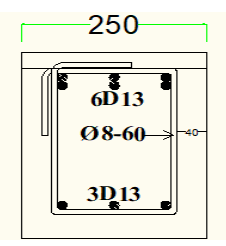

Section 2-2

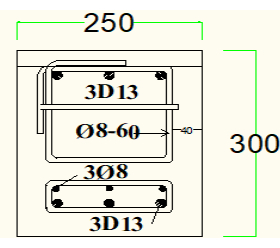

Section 3-3
Fig. 2. Reinforcement of STR-1
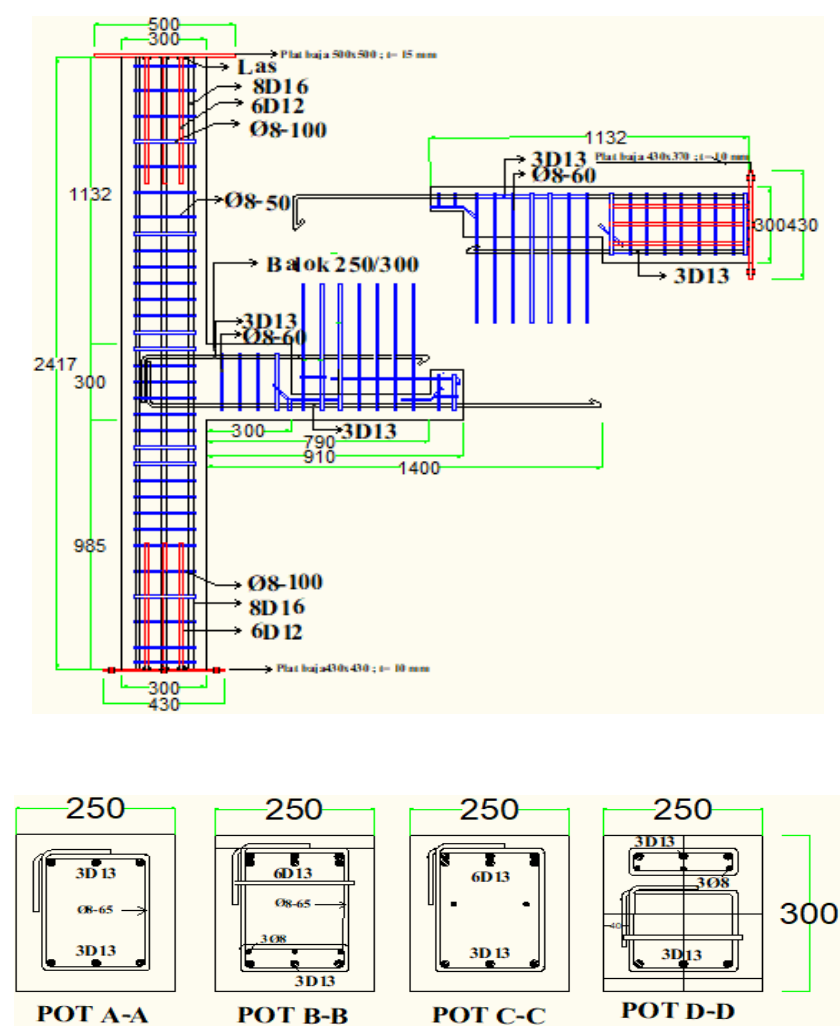

Fig. 3. Reinforcement of STR-2

The Reinforcement detail of STR-1 is shown in Fig. 2. The column was reinforced and with 8D16 longitudinal bars and $\varnothing 8 \mathrm{~mm}$ hoops at $50 \mathrm{~mm}$ spacing. Precast beams were reinforced with 3D13 top and bottom longitudinal bars and with $\varnothing 8$ stirrups at $60-\mathrm{mm}$ spacing. splicing bar 3D13 at the top of the beam are placed at a distance of $300 \mathrm{~mm}$ from the face of the column and splicing bar 3D13 at the bottom of the beam are placed at a distance of $1220 \mathrm{~mm}$ with the same length of $470 \mathrm{~mm}$. The upper and lower longitudinal steel reinforcement of the beam terminated with 90 hooks on the column. The column and beam of STR-2 had the same dimensions and reinforcement as STR-1, however, splicing bar $3 \mathrm{D} 13$ at the bottom of the beam is placed at a distance of 910 $\mathrm{mm}$.

\section{B. Test Setup and Loading Program}

The loading sequence originated from recommendations made by SNI 7834:2012 [3], which has similar requirements with ACI 374.1-05. Column and beam

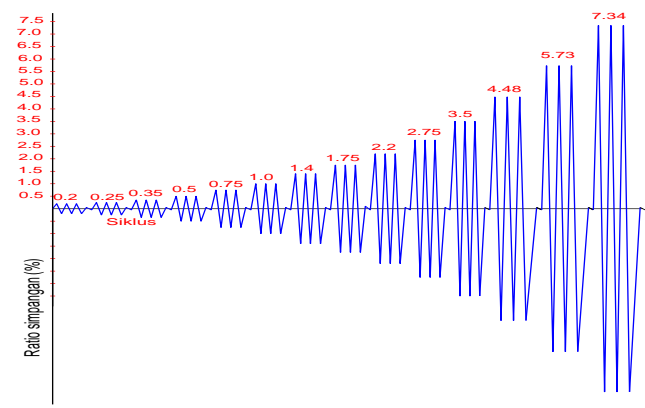

Fig. 4. Loading Program 
ends were pinned (Fig. 1). The test was carried out under deflection control with 3 cycles at each drift ratio. The loading stopped at the maximum drift of $7.34 \%$ or when the test specimens fails with the decrease in lateral load capacity of $20 \%$ or greater from the peak.

\section{RESULTS AND DISCUSSION}

\section{A. Load-Drift Relationship and Cracking Behaviour}

The first crack in the STR-1 specimen occurred in the beam on positive loading $7.4 \mathrm{kN}$, at drift ratio $0.75 \%$. The cracks initially developed on the lower surface of the beam, $20 \mathrm{~cm}$ from the face of the. These is flexure cracks because their path is perpendicular to the loading direction. When the lateral cyclic load continues to increase, a new formation of flexural cracks will appear, extending towards the edge of the beam and increasing in width causing vertical cracks in the thickness of the beam.
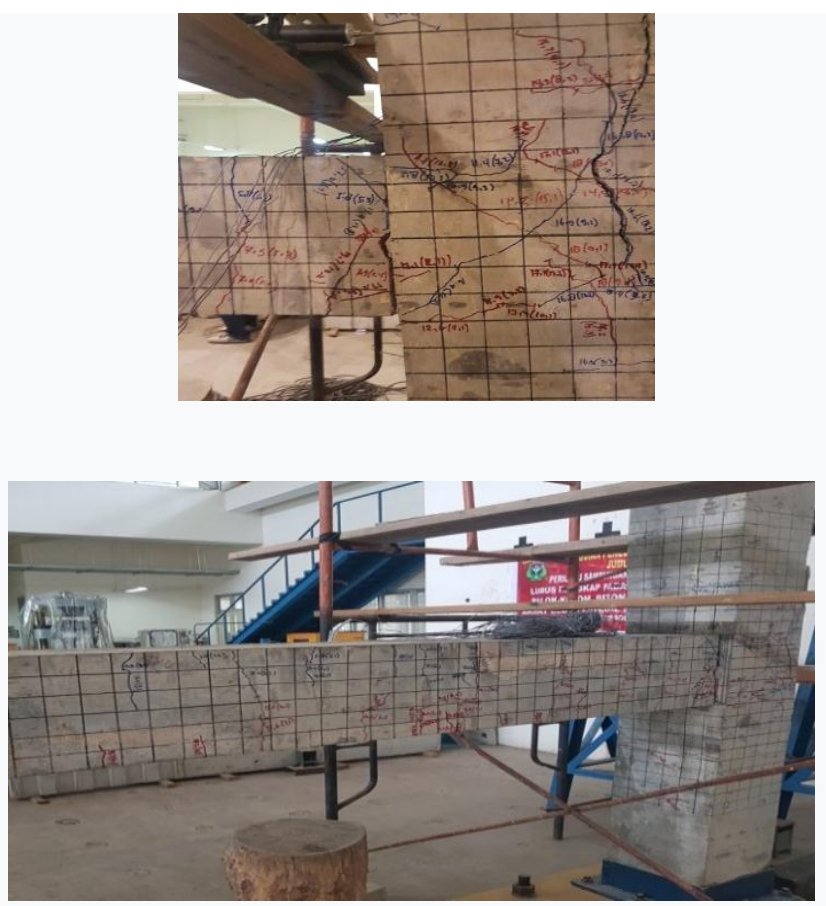

Fig. 5. Crack Pattern of STR-1

When the load continues to increase past its yielding point, the initial flexural crack on the upper side of the beam will meet the bending crack at the bottom side until the circumference of the beam is completely cracked, until plastic hinge is formed. It is also suspected that the increase in crack width during the cracking process occurs because the longitudinal reinforcement has yield. When the load exceeds the maximum capacity or peak load, on drift ratio $5.73 \%$ for positive loads, and $4.48 \%$ for negative loads, this indicates that the load has passed the maximum capacity and dropped to $6.2 \%$ averagely for positive loads, and $2.35 \%$ averagely for negative loads, this is due to spalling on the lower surface of the beam. At the end of the test, the specimen had already collapsed due to negative loading, (lateral force $<80 \%$ Pmax), however has not collapsed at positive loading (lateral force $>80 \%$ Pmax).
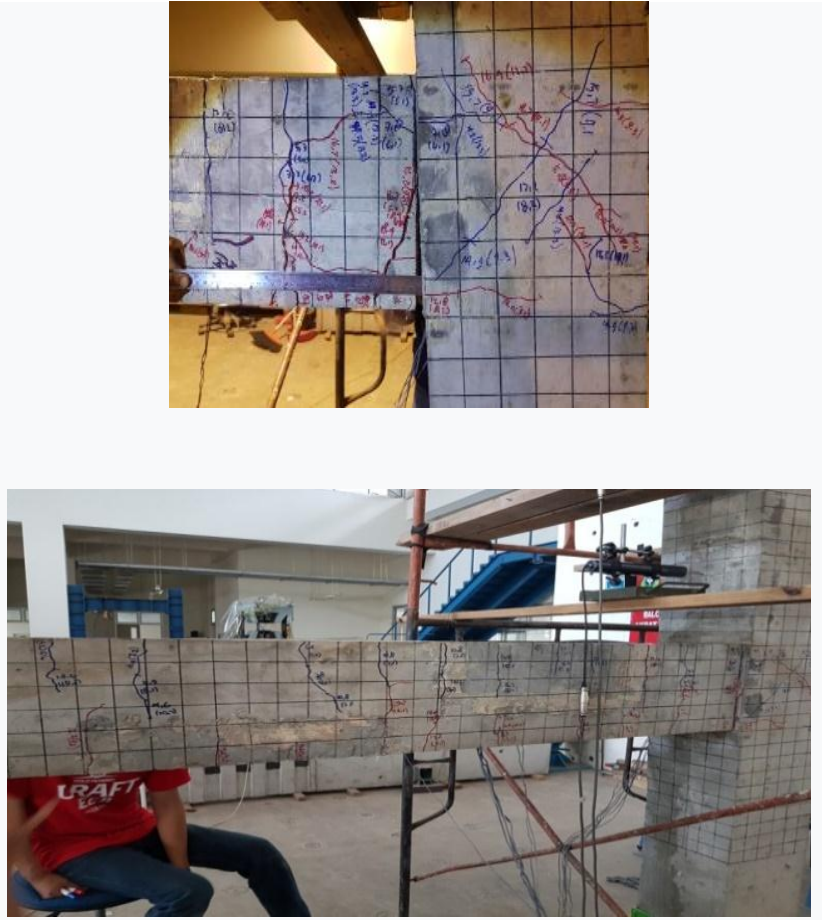

Fig. 6. Crack Pattern of STR-2

Notching system and better quality of grouting cement also make the maximum positive load capacity in STR-1 almost the same with maximum negative load capacity. The maximum positive load STR-2 is $18 \mathrm{kN}$ at drift ratio $7.34 \%$ and 15.10 $\mathrm{kN}$ for maximum negative load at drift ratio $5.73 \%$. This load was lower $10.05 \%$ than monolith for positive load but larger $11.19 \%$ for negative load. Same with STR-1, non-monolithic parts in the STR-2 connection make the maximum positive load capacity on the monolithic specimen is better than STR-2, the notching system and better quality of grouting cement make the maximum negative load capacity in STR-2 better than monolithic. Until the end of the test, there has not been a decrease in strength due to the thrust load $(+)$ and has not collapsed at tensile load (lateral force $>80 \%$ Pmax). In the STR-2 specimen, the maximum positive load capacity is better than the maximum negative load capacity.

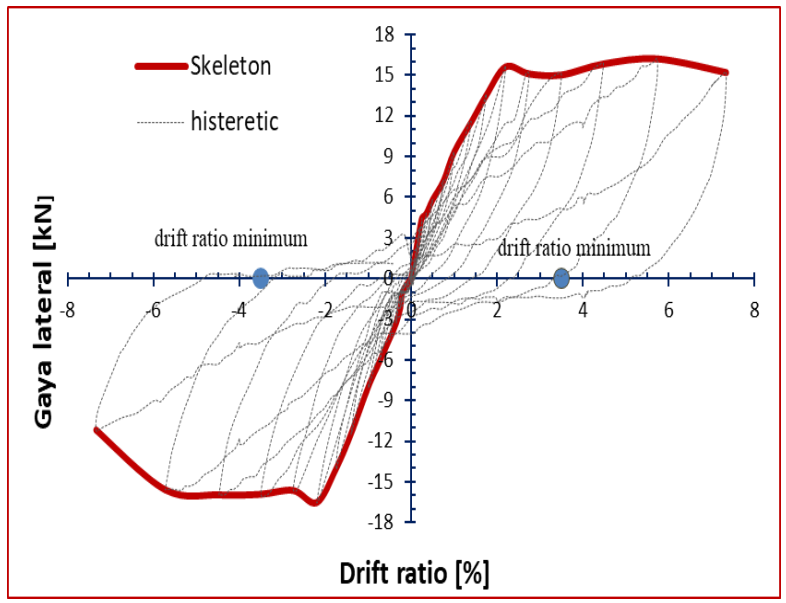

Fig. 7. Hysteresis curves of STR-1 


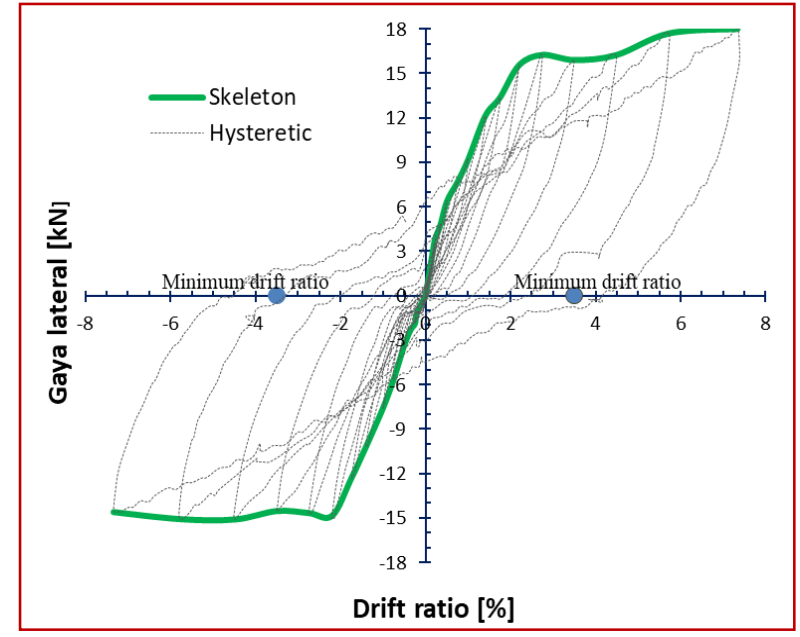

Fig. 8. Hysteresis curves of STR-2

\section{B. Initial Stiffnes}

Based on SNI 7834-2012, the test object is categorized as having sufficient initial stiffness if the specimen reaches the minimum lateral resistance before its deviation ratio of $2 \%$ exceeds the value consistent with the limit of the deviation ratio permitted by the applicable earthquake regulations. Based on Table 1, it is clearly shown that no specimen has a minimum lateral resistance until a minimum drift ratio of $3.5 \%$ is achieved. STR-2 specimens have better minimum lateral resistance capacity than monoliths and STR-1. The evaluation results showed that all test specimens met the initial stiffness requirements as a moment-resisting ductile precast concrete beam-column connection.

Table 1. Acceptance criteria of initial stiffness

\begin{tabular}{|c|c|c|c|c|c|}
\hline 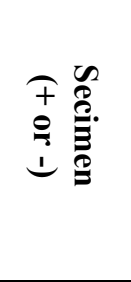 & 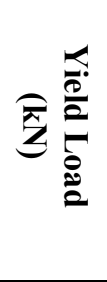 & & 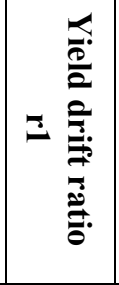 & 竎 & 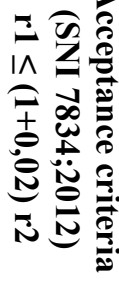 \\
\hline STR-0 + & 17,16 & 63,32 & $2,45 \%$ & $3,50 \%$ & $\mathrm{OK}$ \\
\hline STR-0 - & $-11,26$ & $-38,87$ & $1,51 \%$ & $3,50 \%$ & $\mathrm{OK}$ \\
\hline STR $1+$ & 13,95 & 47,45 & $1,84 \%$ & $3,50 \%$ & $\mathrm{OK}$ \\
\hline STR 1 - & $-13,82$ & $-44,39$ & $1,72 \%$ & $3,50 \%$ & $\mathrm{OK}$ \\
\hline STR $2+$ & 15,97 & 65,35 & $2,53 \%$ & $3,50 \%$ & $\mathrm{OK}$ \\
\hline STR 2 - & $-14,62$ & $-55,67$ & $2,16 \%$ & $3,50 \%$ & OK \\
\hline
\end{tabular}

\section{Strong Column Weak Beam}

The concept of strong column/weak beam in the earthquakeresistant structure is mainly driven by the consideration to construct such proper structural system where the horizontal members, like beam or plate, must fail first before column. In order to let this concept work effectively, it is a necessity to attest that plastic hinge mechanism must occur in the beam rather than column. In correspondence with this matter, SNI $7834 ; 2012$ has specified the minimum requirement need to be satisfied for ensuring that the structure has stronger column members. The maximum lateral resistance shall not have exceeded $\lambda$.Fexp, where $\lambda$ is the specified over strength factor for the test column.

Fig.9 and Fig 10 show the skeleton diagram of strong coumn weak beam for STR-1 and STR-2, and there are no specimen has a maximum lateral resistance value that exceeds the value of the yield force multiplied by the over-column strength factor, as shown in table 2 .

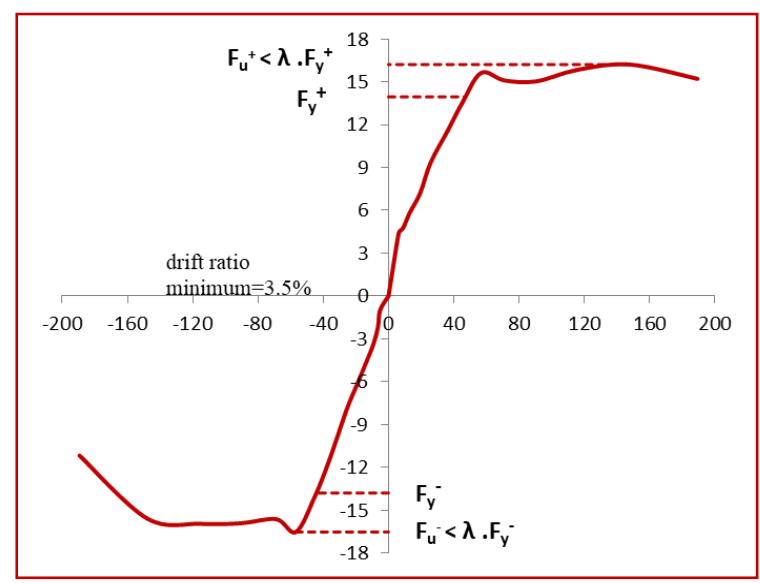

Fig. 9 Strong column weak beam of STR-1

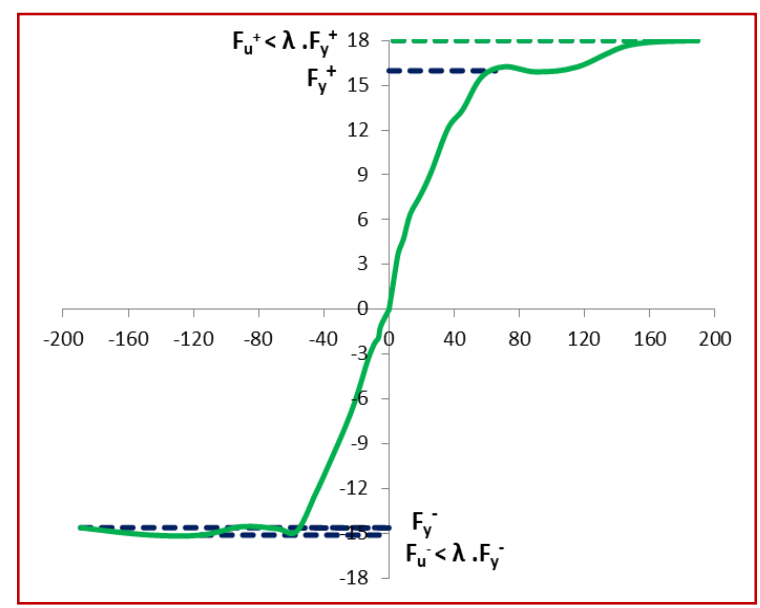

Fig. 10 Strong column weak beam of STR-2 
Table 2. Acceptance criteria of strong column weak beam

\begin{tabular}{|c|c|c|c|c|c|}
\hline 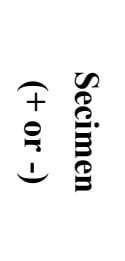 & 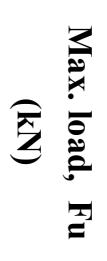 & 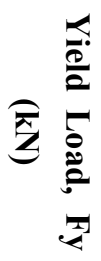 & 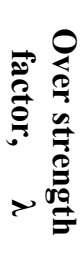 & 妾 ? & 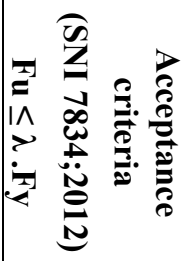 \\
\hline STR-0 + & 20,01 & 17,16 & 3,99 & 68,45 & $\mathrm{OK}$ \\
\hline STR-0 - & $-13,59$ & $-11,26$ & 3,99 & $-44,93$ & $\mathrm{OK}$ \\
\hline STR $1+$ & 16,21 & 13,95 & 3,99 & 55,65 & $\mathrm{OK}$ \\
\hline STR 1 - & $-16,53$ & $-13,82$ & 3,99 & $-55,15$ & $\mathrm{OK}$ \\
\hline STR $2+$ & 18 & 15,97 & 3,99 & 63,73 & $\mathrm{OK}$ \\
\hline STR 2 - & $-15,11$ & $-14,62$ & 3,99 & $-58,35$ & $\mathrm{OK}$ \\
\hline
\end{tabular}

\section{Strength Degradation}

By the SNI 7834:2012 code [3], the evaluation of strenth degradation in the test module are categorized as not degraded strength if the Peak Force is not less than 0.75 maximum load, at a deviation level with a minimum value of 0.035 , the third phase. From what is shown in Table 3, it is evident that all specimens have a sufficient strength reduction of up to $7.34 \%$ drift ratio exceptt STR-1 negative load, up to 5,73\%.

Table 3. Acceptance criteria of strength degradation

\begin{tabular}{|c|c|c|c|c|c|}
\hline 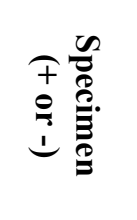 & 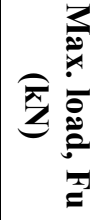 & 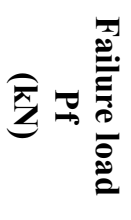 & 离 & 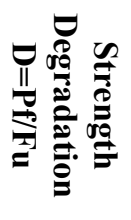 & 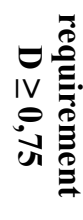 \\
\hline STR-0 + & 20,01 & 17,2 & 7,34 & 0,86 & OK \\
\hline STR-0 - & $-13,59$ & $-13,09$ & 7,34 & 0,963 & OK \\
\hline STR $1+$ & 16,21 & 15,21 & 7,34 & 0,938 & OK \\
\hline STR 1 - & $-16,53$ & $-15,59$ & 5,73 & 0,943 & OK \\
\hline STR $2+$ & 18 & 18 & 7,34 & 1,00 & OK \\
\hline STR 2 - & $-15,11$ & $-14,61$ & 7,34 & 0,967 & OK \\
\hline
\end{tabular}

\section{E. Stiffness Degradation}

By the SNI 7834:2012 code [3], the evaluation of stiffness degradation in the test module is also associated with secant stiffness. The test module is considered to have acceptable stiffness degradation if the ratio of the secant stiffness from a drift ratio of $\pm 3.5 \%$ over the initial drift ratio of $\pm 0.35 \%$ equals to or exceeds the value of 0.05 . The stiffness at a $3.5 \%$ drift ratio is calculated for each specimen [13].
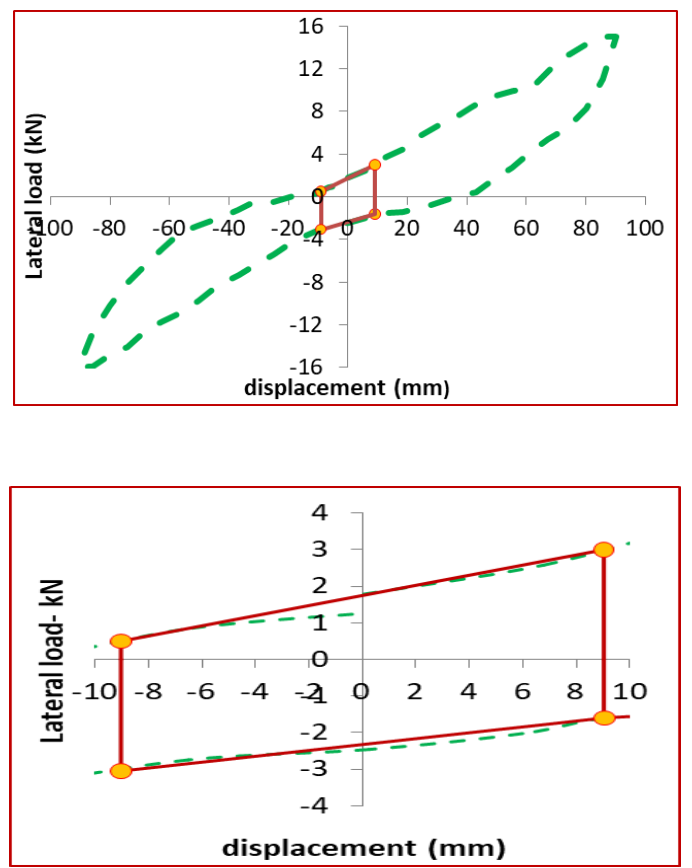

Fig. 11. Stiffness degradation of STR-1
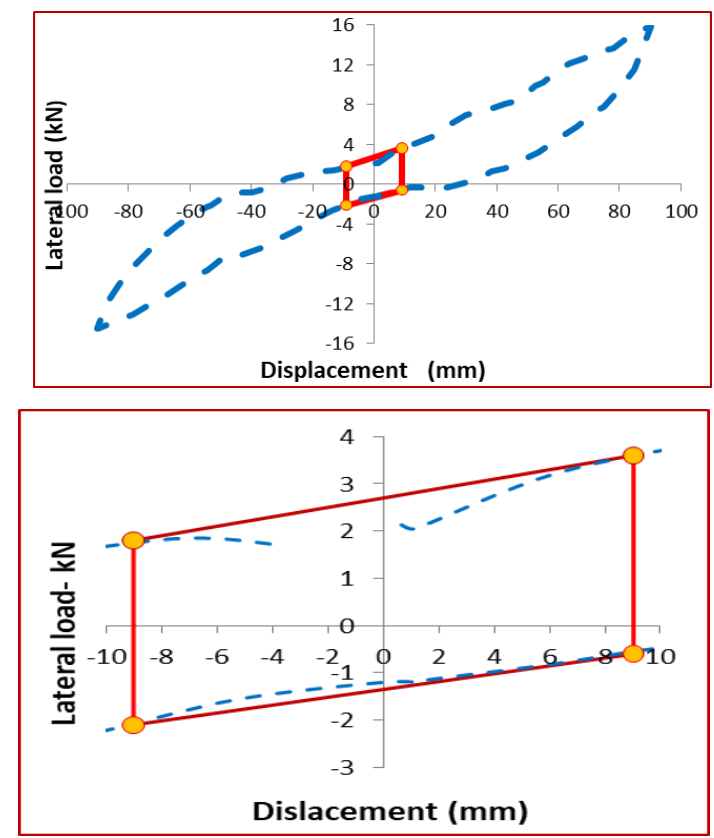

Fig. 12. Stiffness degradation of STR-2

The slope from point A to A 'is described as the stiffness in the direction of the thrust loading. whereas the stiffness in the direction of tensile loading is described as the slope from point $\mathrm{B}$ to $\mathrm{B}$ '. Points $\mathrm{C}$ and $\mathrm{D}$ show an initial deviation ratio of $0.35 \%$ and $+0.35 \%$, respectively. Table 4 summarizes the evaluation of stiffness reduction that each specimen has in both positive and negative directions. From what is shown in Table 4, it is evident that all specimens have a sufficient 
stiffness reduction of up to $3.5 \%$ drift ratio. This suggests that all specimens can maintain their stability when subjected to lateral cyclic loads, and not only provide adequate initial stiffness but also reduce the degradation of lateral stiffness during increased lateral loads.

\section{F. Dissipation Energy}

Energy dissipation of concrete structures is one of the fundamental capacities that determines the structure's resistance to earthquake loads. The amount of dissipation energy for each loading cycle is calculated as the area of the area bounded by the load deflection hysteresis loop in the third cycle structure for each drift ratio value. The relative energy dissipation is defined as the ratio of actual to ideal energy dissipated by test specimen during reversed cyclic response between given drift ratio limits.

The actual energy dissipation is expressed as the area in the hysteretic loop per load cycle. The ideal energy dissipation is defined as the area of the circumscribing parallelograms $\mathrm{ABCD}$ and DEFA in the elastoplastic condition during the third cycle of $3.5 \%$ drift ratio. These parallelograms are formed according to the following process as shown in Fig. $13[13]$

1. The slope lines $\mathrm{AB}$ and $\mathrm{CD}$ are parallel to $\mathrm{OA} 1$, representing the initial stiffness in the positive direction

2. the slope lines FA and DE are parallel to OA2, depicting the initial stiffness in the negative direction (line DE for reversed loading and FA for unloading);

Table 4. Acceptance criteria of stiffness degradation

\begin{tabular}{|c|c|c|c|c|c|c|}
\hline \multirow{2}{*}{$\begin{array}{c}\text { Speciment } \\
(+ \text { or }-)\end{array}$} & \multirow{2}{*}{$\begin{array}{l}\text { Initial stiffness } \\
\text { Ko (kN.mm) }\end{array}$} & \multicolumn{2}{|c|}{ Secant load di $3,5 \%$} & \multirow{2}{*}{$\begin{array}{c}\text { Secant } \\
\text { stiffness at - } \\
3,5 \%, K^{\prime} \\
(\mathrm{N} / \mathbf{m m})\end{array}$} & \multirow{2}{*}{$\begin{array}{c}\text { Ratio of } \\
\text { K' over } \\
\text { Ko } \\
\text { (rs) }\end{array}$} & \multirow{2}{*}{$\begin{array}{c}\text { requirement } \\
\text { rs } \geq 0,05\end{array}$} \\
\hline & & $\begin{array}{c}\text { Load at } \\
\text { drift }+0,35 \% \\
(k N)\end{array}$ & $\begin{array}{c}\text { Load at drift } \\
-0,35 \%(k N)\end{array}$ & & & \\
\hline STR 0+ & 0,669 & 4,7 & 2,78 & 0,106 & 0,16 & OK \\
\hline STR 0 - & 0,427 & 0,6 & $-0,8$ & 0,078 & 0,18 & $\mathrm{OK}$ \\
\hline STR 1+ & 0,738 & 3 & 0,5 & 0,138 & 0,19 & OK \\
\hline STR 1 - & 0,298 & $-1,6$ & $-3,05$ & 0,080 & 0,27 & OK \\
\hline STR 2+ & 0,657 & 3,6 & 1,8 & 0,100 & 0,15 & $\mathrm{OK}$ \\
\hline STR 2 - & 0,227 & $-0,6$ & $-2,1$ & 0,083 & 0,37 & OK \\
\hline
\end{tabular}

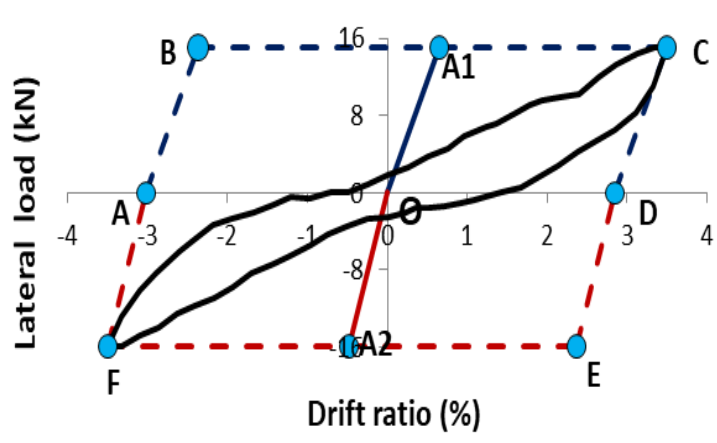

Fig. 13. Relative and Ideal energy dissipation

3. lines $\mathrm{BC}$ and $\mathrm{EF}$ describe the peak lateral load in the loading and reversed loading condition respectively.

To see the stability of the structural system at the maximum displacement level due to cyclic loads, ACI 374.1-05 requires the relative energy dissipation ratio shall have been not less than 1/8 calculated based on the third cycle at the end of loading history. The ideal energy dissipation $\left(E_{i}\right)$ and relative energy dissipation $E_{r}$ can be calculated by referring to the Equation (1) and (2).

In Fig. 14 and 15 seen in each specimen, the dissipation energy tends to increase due to an increase in drift level, but for each repetition cycle at each drift level, the same amount of dissipation energy tends to decrease. This is caused by the development of cracks at the same drift level which is relatively constant (no significant new cracks have formed) or only the cracking widening occurs at the same location. Total energy cumulative at drift $7.34 \%$ of STR-2 is $10,164.15 \mathrm{KN}$ $\mathrm{mm}$, monolith is $9,306.80 \mathrm{KN}$ mm and STR-1 is $8,363.34 \mathrm{KN}$ $\mathrm{mm}$. STR-2 looks more able to maintain its strength against the influence of the cyclic thrust and pull loads. Referring to the results of tests that have been done, the relative dissipation energy ratio $\beta$ in the three test objects shows values greater than $1 / 8(0.125)$, so they still meet the criteria required by ACI 374.1-05 or it mean the structure still has the ability to maintain its stability before it collapses. 


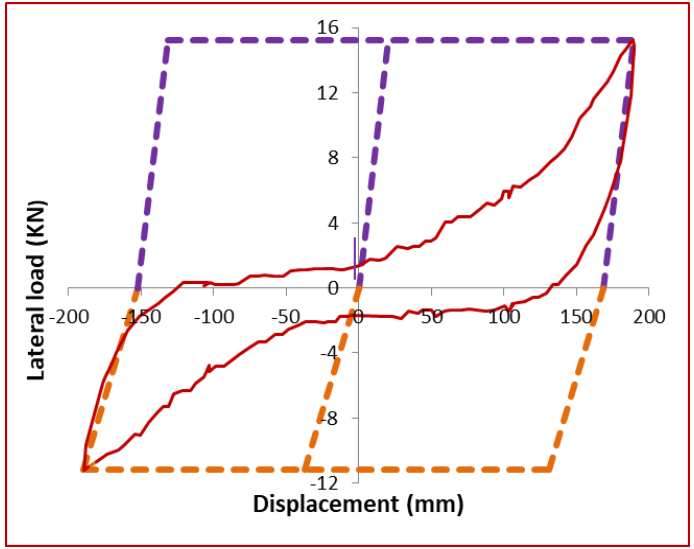

Fig. 14. Relative energy dissipation STR-1

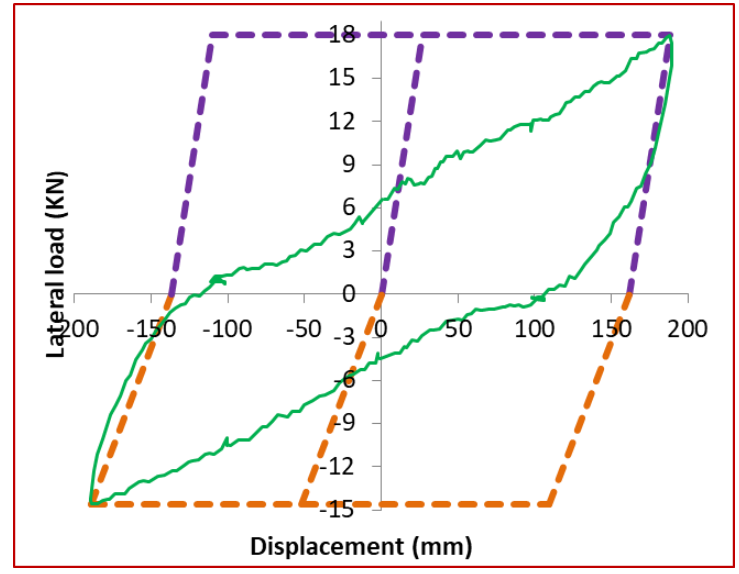

Fig. 15. Relative energy dissipation STR-2

Table 5. Acceptance criteria of relative energy dissipation

\begin{tabular}{|c|c|c|c|c|c|c|c|c|}
\hline Speciment & \multicolumn{2}{|c|}{$\begin{array}{c}\text { Ideal energy dissipation } \\
\text { (kN-mm) }\end{array}$} & $\begin{array}{c}\text { Actual energy dissipation } \\
\text { (kN-mm) }\end{array}$ & relatif energy dissipation ( $\beta)$ & \multicolumn{2}{c|}{$\begin{array}{c}\text { requirement } \\
\beta \geq \mathbf{1 / 8}\end{array}$} \\
\hline & drift 3.5\% & drift 7.34\% & drift 3.5\% & drift 7.34\% & $\begin{array}{c}\text { Drift min. } \\
\mathbf{3 . 5} \%\end{array}$ & $\begin{array}{c}\text { drift 7.34\% } \\
\text { (end of test) }\end{array}$ & $\begin{array}{c}\text { drift } \\
\mathbf{3 . 5 \%}\end{array}$ & $\begin{array}{c}\text { drift } \\
\mathbf{7 . 3 4} \%\end{array}$ \\
\hline STR-0 & 3523 & 9444 & 608 & 3293 & 0,172 & 0,348 & OK & OK \\
\hline STR-1 & 3308 & 84612 & 1029 & 2018 & 0,311 & 0,230 & OK & OK \\
\hline STR-2 & 3194 & 9711 & 938 & 3900 & 0,293 & 0,401 & OK & OK \\
\hline
\end{tabular}

\section{G. CONCLUSIONS}

Based on the observation and results during construction, testing and data analysis, the following conclusions were developed.

1. Crack pattern of all specimens is a flexible crack. Compared to monolith, the use of high-grade mortar and notch restraint systems increases the rigidity and strength of the joints. this forces the position of the plastic hinge to move towards the weaker section and accept a large moment. Finally, the position of the plastic hinge at the joint is shifting by $45 \mathrm{~mm}$ on STR-1 and $50 \mathrm{~mm}$ on STR-2 towards the face of the column.

2. Although the monolith and STR-1 specimens have the highest level of strength in the thrust $(+)$ and tensile (-) direction loads, on the other hand, the STR-2 specimens have the lowest strength and stiffness degradation and the highest energy dissipation until the end of the test. This indicates that the STR-2 joint specimen has the highest level of toughness and ability to maintain its strength against deformation during the test.

3. Both types of precast connections generally comply the requirements as an moment-resisting ductile precast concrete beam-column connection and can be safely applied to precast reinforced concrete building with the highest earthquake risk.

\section{H. FUTURE SCOPE}

The results of this research are two connection models that are economical and easy to implement at the beam-column connection of precast concrete, which can be used in buildings with the highest earthquake risk level in Indonesia.

\section{REFERENCES}

[1] American Concrete Institut Standard. Acceptance Criteria for Moment Frames Based on Structural Testing and Commentary, (ACI 374.1-05). USA : ACI Committee 374, 2005.

[2] American Concrete Institut Standard. Building Code Requirements for Reinforce Concrete, (ACI 318-89). Illionis, USA: ACI Committee 318, 1989.

[3] Standar Nasional Indonesia. Metode Uji dan Kriteria Penerimaan Sistem Struktur Rangka Pemikul Momen Beton Bertulang Pracetak untuk Bangunan Gedung, (SNI 7834-2012). Jakarta : Badan Standardisasi Nasional, 2012.

[4] Standar Nasional Indonesia, Tata Cara Perencanaan Ketahanan Gempa untuk Bangunan Gedung dan Non Gedung, (SNI 1726-2019. Jakarta : Badan Standardisasi Nasional, 2019. 
[5] Standar Nasional Indonesia, Persyaratan beton structural untuk Bangunan Gedung, (SNI 2847-2013. Jakarta : Badan Standardisasi Nasional, 2013.

[6] Gideon H Kusuma. Desain Struktur Rangka Beton Bertulang di Daerah rawan Gempa, $2^{\text {nd }}$ Edition. Jakarta : Erlangga, 1993.

[7] Mardew Jamal, Herman Parung, Wihardi Tjaronge and Victor Sampebulu. Ductility of The Precast and Monolith Concrete on Beam Column Joints Under Cyclic Loading. Journal of Engineering and Applied Sciences, 9, 2014, pp. 101-108.

[8] J. Y. Lee, J. Y. Kim and G. J. Oh. Strength deterioration of reinforced concrete beam-column joints subjected to cyclic loading. Journal of Engineering Structures, 31, 2009, pp. 2070-2085.

[9] Ghosh, S.K, Nakaki, S.D. and Krishnan, K. Precast Structures in Regions of High Seismicity 1997 UBC Design Provisions. PCI Journal, Precast/Prestressed Concrete Institute, 42, 1997, pp. 76-93.

[10] Ruminsar Simbolon, Herman Parung, Rita Irmawaty and Arwin Amiruddin. Daktilitas Sambungan Model Takikan Rangkap Pada Hubungan Balok-Kolom Beton Pracetak, Akibat Beban Lateral Siklik. Sektran Journal, 7, 2019, pp. 162-171

[11] Sergio M Alcocer1, Rene Carranza and David PerezNavarrete. Behaviour of a Precast Concrete BeamColumn Connection. 12WCEE Journal, 2000, pp. 15431550 .

[12] Heinzelman, W. Application-Specific Protocol Architectures for Wireless Networks. Ph.D. Dissertation, Cambridge: Massachusetts Institute of Technology, 2000.

[13] Asdam Tambusay. Cyclic Behaviour of Slab-Column Connections using the Engineered Cementitious Composite. Ph.D. Dissertation: Institut Teknologi Sepuluh Nopember, Surabaya, Indonesia, 2017.

[14] Han Qian. Behaviour of Precast Reinforced BeamColumn connections under static and repeated loading. Ph.D. Thesis : The University of Wollongong, 1994. http://ro.uow.edu.au/thesis/2421. 